\title{
The Improvement of Fiction Prose Study as a Teaching Material Based on Makassar Local Wisdom Integrated with Mobile Learning at FKIP Universitas Muhammadiyah Makassar
}

\author{
Haslinda \\ Universitas Negeri Makassar, Jalan Bonto Langkasa, Kampus Gunung Sari, Makassar, South Sulawesi, Indonesia \\ Muhammad Rafi Tang \\ Universitas Negeri Makassar, Jalan Bonto Langkasa, Kampus Gunung Sari, Makassar, South Sulawesi, Indonesia \\ Andi Sukri Syamsuri \\ Universitas Negeri Makassar, Jalan Bonto Langkasa, Kampus Gunung Sari, Makassar, South Sulawesi, Indonesia
}

\begin{abstract}
The purpose of this research was to produce the prototype of fiction prose study as the valid, effective, and practical teaching material based on Makassar local wisdom integrated with mobile learning. It applied research and development (R\&D) by using Analyze, Design, Develop, Implement, Evaluation (ADDIE) method. The samples of this research were from the students of Indonesian Language and Literature Study Program, Faculty of Teacher Training and Education (FKIP) of Universitas Muhammadiyah Makassar. Technique of data collection included test, questionnaires, observations, interviews, and documentation. The data were analyzed by qualitative descriptive and descriptive statistics. The finding of this research was the fiction prose study as a valid teaching material based on Makassar local wisdom integrated with mobile learning reviewed from its contents, presentation, graphic, language, and technology source. It was proven from the result of preliminary field test which indicated the teaching material as in high validation category. Similarly, the results of main field test and operational field test showed the same category as well. In conclusion, the teaching material was effective to improve students' understanding related to the values of Makassar local wisdom along with their learning result. It was also a practical material referred to its implementation and management in learning process.
\end{abstract}

Index Terms - teaching material, mobile learning, and local wisdom

\section{INTRODUCTION}

The essential of research and development in teaching material based on local wisdom referred to Indonesia's curriculum focusing on the educational development using local wisdom (Susanto, 2014). The fiction prose study is one of subjects in literatures department. It is regarded that literature is an appropriate tool in teaching culture. Literature can be used as a teaching tool, manual book, instructional book, or teaching material (Teeuw, 1984). A literary work is an attempt to record the contents of an author's soul (Sumardjo and Saini, 1994). Specifically, Pradopo (2011) suggested that literary work is a work of art which requires creativity and imagination. Besides, literature presents life which is mostly composed by social reality, although it is seemed to imitate nature and subjective world of men existence (Wellek and Warren, 1993). Related to the term of literature, Semi (1993) described it as a form or result of creative art with men and their existence as the objects and language as the medium. Also, Sumardjo and Saini (1994) explained that literature are personal expressions of experience, thought, feeling, ideas, spirit, and belief in the form of concrete description which evoke its own beauty through a language.

Pursuing this further, literature is an imaginative work. One of them is prose which defined as a series of a specific story based on author's imagination which becomes a complete story (Aminuddin, 2011). Even as an imaginative work, it does not come from empty space with no meaning. Literature comes from social life which brings message and philosophy of the society where it comes (Abrams, 1981). The forms of literary works which become focus of this research are novel and short story. Abrams (1981) explained that novel is an extended short story, and after being extended it is called as a romance. While Waluyo (1994) illustrated novel as a new art symbol adapted from facts and author's experiences. Additionally, the story line of a novel is something realistic and reasonable (Stanton, 2012).

In the same way, short story is a story which can be completed in one sitting, around one to two hours, something that is impossible for a novel (Jassin, 2008). In line with the statement above, short story is a narration (not an 
argumentative analysis) or a fiction (unreal but may be found at any time and place) which relatively short (Sumarjo and Saini, 1994: 37).

There are three accessible ways in culture learning, that is through teaching material, method, and authentic assessment (Mulyana in Rukanah, 2017). National Center for Competency Based Training in Prastowo (2013) stated that teaching material is every item that helps lecturers or instructors in teaching and learning process. Equally important, teaching material is every tool used to help students in teaching and learning process (Kemendiknas, 2010). Similarly, Dick, Carey \& Carey (2009) added that "teaching material is a systematic set of material or substance as a complete representation of competence by the students to achieve in learning process". Juneau (Fitraningum, 2015) also stated that teaching material is a source used in teaching process based on printed or non-printed curriculum and published materials made by lecturers. On the other side, Opara and Oguzor (2011) asserted that teaching material is the learning source in the form of audio visual (software/hardware) used as a communication's alternative in teaching and learning process.

Teaching material's validity in development research includes content and construct validity as well. Akker (1999) clarified that validity refers to the level of intervention design based on the state-of-the-art knowledge and how various components of the intervention are linked to each (construct validity). He added that the practicality indicator refers to some level that users (other experts) consider the intervention as more applicable and preferable in normal condition. Moreover, the effectiveness of teaching material concerns about the level of experience and the results of regular intervention as aimed.

The developing teaching material based on mobile learning uses EPUB application which can be accessed through android mobile phone with the assistance of Ideal Group Leader. Ally (2009) defined that mobile learning delivers electronic material on a computing mobile device to be more accessible. Equally, Traxler (2007) has written, “...therefore, mobile learning is not only about 'mobile device' or 'learning' matter as previously understood, but it is a part of a concept of new dynamism in society." The research about mobile learning and its reflection must stimulate multidisciplinary and interdisciplinary thinking and educational methods (El-Hussein, 2010). The expectation of learning effectiveness by implementing technology is aligned with the statement uttered by Vocoula and Sharples (2009) that in this era of advanced technology, mobile learning (M-learning) is a potential opportunity to improve the quality of learning.

\section{RESEARCH METHOD}

This research was a research and development (R\&D) design. It adapted Molenda's (2008) design or known as ADDIE which includes five stages, that is analyzing, designing, developing, implementing, and evaluating. By observing its field test, this research was classified as pre-experimental design with pre-test and post-test. Though the data collection indicated that it applied mixed method design as well.

The research was conducted at Universitas Muhammadiyah Makassar located in Jalan Sultan Alauddin No. 259, Makassar City, South Sulawesi Province, Indonesia. It was held on fourth semester (odd semester) of 2016-2017 Academic Year. Also, the samples of this research were 142 students in fourth semester of Indonesian Language Education and Literatures study program. Specifically, six samples were placed in preliminary field test, twelve samples in main field test and twenty four samples in operational field test. One hundred samples who were taught by specific materials divided into three classes. The instruments of this research and development included: (a) questionnaire sheets of content/material validity assessment; (b) learning result test; (c) observation sheets of learning implementation and material management; (d) questionnaire of lecturers' and students' response; (e) interviews; and (f) documentation. The analysis of quantitative data used descriptive statistical technique which covered final score, criteria average, aspect average, and total average. For the qualitatiave data, it was analyzed by using qualitative descriptive technique.

\section{RESUlTS AND ANALYSIS}

a. Description of Material Validity

1. Description of teaching material validity

TABLE 1

VALidATION RESUlts OF TEACHING MATERIAL (FIRST AND SECOND PROTOTYPE)

\begin{tabular}{|c|c|c|c|c|}
\hline Aspect & $\begin{array}{l}\text { First Test } \\
\text { Average Score }\end{array}$ & Description & $\begin{array}{l}\text { Second Test } \\
\text { Average Score }\end{array}$ & Description \\
\hline $\begin{array}{l}\text { Material Compatibility of Standard Competence } \\
(S K) \text { and Basic Competence }(K D)\end{array}$ & 3.00 & Fair & 4.00 & Valid \\
\hline Material Accuracy & 3,25 & Fair & 4,25 & High Validity \\
\hline Material Renewal & 3.00 & Fair & 4.50 & High Validity \\
\hline Engaging Curiosity & 2.50 & Poor & 4.50 & High Validity \\
\hline Total Average Score & 2,85 & Fair & 4,32 & High Validity \\
\hline
\end{tabular}

Table 1 above showed the validation results of teaching material of first and second prototype. Total average score of the first prototype's validation was 2,85 (fair) and the second prototype's validation was 4,32 (high validity). 
2. Description of material presentation validity

TABLE 2

VALIDATION RESUlTS OF SySTEMATIC MATERIAL PRESENTATION (FIRST AND SECOND PROTOTYPE)

\begin{tabular}{|l|l|l|l|l|}
\hline Aspect & $\begin{array}{l}\text { First Test } \\
\text { Average Score }\end{array}$ & Description & $\begin{array}{l}\text { Second Test Average } \\
\text { Score }\end{array}$ & Description \\
\hline Presentation Technique & 2,00 & Poor & 4,25 & HighValidity \\
\hline Presentation Supplement & 2,25 & Poor & 4,00 & Valid \\
\hline Material Presentation & 2,88 & Fair & 4,00 & Valid \\
\hline Coherence and Cohesion of Conceptual Thinking & 2,25 & Poor & 4,00 & Valid \\
\hline Total Average Score & 2,35 & Poor & 4,07 & Valid \\
\hline
\end{tabular}

Table 2 above showed the validation results of presentation systematic elements in the first and second prototype. The total average score of the first prototype's validation was 2,35 (poor) and the second prototype's validation was 4,07 (valid).

3. Description of teaching material's graphic validity

TABLE 3

VALIDATION RESULTS OF TEACHING MATERIAL'S GRAPHIC (FIRST AND SECOND PROTOTYPE)

\begin{tabular}{|l|l|l|l|l|}
\hline Aspect & First Test Average Score & Description & Second Test Average Score & Description \\
\hline Size of Printed Material (optional) & 4,00 & Valid & 4,00 & Valid \\
\hline Cover Design & 2,50 & Poor & 4,75 & High Validity \\
\hline Content/Material Design & 2,50 & Poor & 4,25 & High Validity \\
\hline Total Average Score & 3,00 & Fair & 4,33 & High Validity \\
\hline
\end{tabular}

Table 3 above showed the validation results from the experts relating the graphic structures of the first and second prototype. The total average score of graphic structure in the first prototype's validation was 3,00 or categorized as fair and the second prototype's validation was 4,33 which in high validity category.

4. Description of language validity in teaching material

TABLE 4

VALIDATION RESUlts OF LANGUAGE USED In TEACHING MATERIAL (FIRST AND SECOND PROTOTYPE)

\begin{tabular}{|l|l|l|l|l|}
\hline Aspect & First Test Average Score & Description & Second Test Average Score & Description \\
\hline Directness & 3,13 & Fair & 4,13 & \\
\hline Communicativenes & 3,25 & Fair & 4,50 & Valid \\
\hline Dialogic interaction & 2,88 & Fair & 3,88 & High Validity \\
\hline Compatible with students' development & 3,25 & Fair & 4,25 & Valid \\
\hline Compatible with grammar & 3,00 & Fair & 4,00 & High Validity \\
\hline The use of terms, symbols, and icons & 2,88 & Fair & 4,38 & Valid \\
\hline Total Average Score & $\mathbf{3 , 0 6}$ & Fair & 4,19 & High Validity \\
\hline
\end{tabular}

Table 4 above showed the validation results of language used in teaching material in the first and second prototype. The total average score in first prototype's validation was 3,06 (fair) and the second prototype's validation was 4,19 or in valid category.

5. Description of technology/media validity in teaching material

TABLE 5

VALIDATION RESUlts OF TECHNOLOGY/MEDIA USED IN TEACHING MATERIAL (FIRST AND SECOND PROTOTYPE)

\begin{tabular}{|l|l|l|l|l|}
\hline Aspect & First Test Average Score & Description & Second Test Average Score & Description \\
\hline Visual Communication Design & 3,00 & Fair & 4,25 & High Validity \\
\hline Software Utilization & 3,00 & Fair & 4,13 & Valid \\
\hline Total Average Score & 3,00 & Fair & 4,19 & Valid \\
\hline
\end{tabular}

Table 5 above showed the validation results of technology/media used in teaching material in the first and second prototype. The total average score in first prototype's validation was 3,00 (fair) and the second prototype's validation was 4,19 (valid).

6. Description of syllabus and lesson plan validity

TABLE 6

VALIDATION RESULTS OF THE SYLLABUS

\begin{tabular}{|l|l|l|l|l|}
\hline \multirow{2}{*}{ Aspect } & \multicolumn{2}{|l}{ VALIDATION RESULTS OF THE SYLLABUS } & \multirow{2}{*}{ Total Aspect } & \multirow{2}{*}{ Description } \\
\cline { 2 - 5 } & I & II & 4,25 & High Validity \\
\hline Content Review & 4,25 & 4,25 & 4,13 & Valid \\
\hline Language & 4,00 & 4,25 & 4,00 & Valid \\
\hline Time Allocation & 4,00 & 4,00 & 4,38 & High Validity \\
\hline Source Reliability & 4.50 & 4,25 & 4,00 & Valid \\
\hline Soft Skill & 4,00 & 4,00 & 4,15 & Valid \\
\hline Total Average Score & 4,12 & 4,25 & \\
\hline
\end{tabular}


Table 6 above showed the validation results of the syllabus used. The total average score of the syllabus was 4,15 or in valid category.

TABLE 7

VALIDATIONRESULTS OF THE LESSON PLAN

\begin{tabular}{|l|l|l|l|l|}
\hline \multirow{2}{*}{ Aspect } & \multicolumn{2}{|l|}{ Validator's Average Score } & \multirow{2}{*}{ Total Aspect Score } & \multirow{2}{*}{ Description } \\
\cline { 2 - 3 } & I & II & 4,75 & High Validity \\
\hline Objectives Formulation & 5,00 & 4,50 & 4,00 & Valid \\
\hline Content Review & 4,00 & 4,00 & 4,00 & Valid \\
\hline Language & 4,00 & 4,00 & 4,38 & High Validity \\
\hline Clarity of Learning Steps & 4.50 & 4,25 & 4,00 & Valid \\
\hline Assessment/Evaluation & 4,00 & 4,00 & 4,23 & High Validity \\
\hline Total Average Score & 4,30 & 4.15 & & \\
\hline
\end{tabular}

Table 7 above showed the validation results of the lesson plan. The he total average score of the lesson plan was 4,23 or in high validity category.

7. Description of material validity based on field tests result

After the material and its supporting tools were validated by the experts, the next steps would be preliminary field test, main field test, and operational field test.

TABLE 8

SAMPLES' RESPONSES IN FIELD TESTS

\begin{tabular}{|c|c|c|c|}
\hline Field Test Group & $\Sigma$ Sample & Total Average Score & Description \\
\hline Preliminary Field Test & 6 & 3,75 & Good \\
\hline Main Field Test & 12 & 4,38 & Very Good \\
\hline Operational Field Test & 24 & 4,88 & Very Good \\
\hline
\end{tabular}

Table 8 above showed the results of samples' responses in preliminary field test was in good category with total average score of 3,75 , while the main field test was in very good category with total average score of 4,38 . The results of samples' response of operational field was in very good category with total average score of 4,88 .

Other responses for supporting the validity were obtained from model lecturer. Here is the following table below involving model lecturers' responses:

TABLE 9

MODEL LECTURERS' RESPONSES IN FIELD TESTS

\begin{tabular}{|l|l|l|l|}
\hline Model Lecturer & $\boldsymbol{\Sigma}$ Lecturer & Total Average Score & Description \\
\hline Preliminary Field Test & 1 & 4,25 & Very Good \\
\hline Main Field Test & 1 & 4,25 & Very Good \\
\hline Operational Field Test & 1 & 4,50 & Very Good \\
\hline
\end{tabular}

Table 9 above showed the results of model lecturers' responses in the preliminary field test as in very good category with total average score of 4,25. A similar result in the main field test with total average score of 4,25 or in very good category and in the operational field test with total average score of 4,50 which also categorized as very good.

\section{b. Description of Material Effectiveness}

In the preliminary field test, there were no students who answered the questions perfectly. The lowest score was 23 with only 14 correct answers (sample number 66), while the highest score was 85 with 51 correct answers (sample number 35). By large, only 22 students (22\%) passed the test. The results proved that the students' basic ability in the pre-test were pretty poor. Nevertheless, after the treatment given, the test result of sample number 23 had a significant increase by obtaining 68 scores with 41 correct answers. The result cannot make the student pass the test yet, but at least it gave an increase of $27 \%$. Related to that, the lowest score in post-test was from sample number 66 with total score 38 and 23 correct answers. The highest score was from sample number 35 with total score of 100 and 60 correct answers. In other words, there were 76 students or $76 \%$ who passed the test after learning the developing teaching material with an average increase of $54 \%$.

Moreover, the test results of students' knowledge and understanding about Makassar's local wisdom showed that they were able to find the right values of local wisdom in a piece of literary work with $91 \%$ complete percentage. On the other hand, $9 \%$ students failed to meet the completeness criteria because they could not understand and relate the values with real life.

c. Description of Learning Implementation and Management

1. Description in teaching material implementation

The total students in Class Implementation I were 34 students. The results of teaching material implementation are presented on the following table: 
TABLE 10

LEARNING IMPLEMENTATION OF CLASS IMPLEMENTATION 1, 2, AND 3

\begin{tabular}{|c|c|c|c|c|c|c|c|}
\hline No. & Aspect & $\begin{array}{l}\text { Average } \\
\text { Score of } \\
\text { Class } 1 \\
\end{array}$ & Description & $\begin{array}{l}\text { Average } \\
\text { Score of } \\
\text { Class } 2 \\
\end{array}$ & Description & $\begin{array}{l}\text { Average } \\
\text { Score of } \\
\text { Class } 3\end{array}$ & Description \\
\hline 1 & $\begin{array}{l}\text { Lecturer's style in outlining } \\
\text { learning objectives }\end{array}$ & 4,50 & Very Good & 4,50 & Very Good & 5,00 & Very Good \\
\hline 2 & Guiding students & 4,00 & Good & 4,50 & Very Good & 4,50 & Very Good \\
\hline 3 & Skill in directing the groups & 4,00 & Good & 4,00 & Good & 4,50 & Very Good \\
\hline 4 & Mastering the material concept & 4,50 & Very Good & 4,50 & Very Good & 4,50 & Very Good \\
\hline 5 & $\begin{array}{l}\text { Giving motivation to students } \\
\text { to learn }\end{array}$ & 4,50 & Very Good & 4,50 & Very Good & 5,00 & Very Good \\
\hline 6 & $\begin{array}{l}\text { Lecturer's ability in monitoring } \\
\text { groups' activities }\end{array}$ & 4,00 & Good & 4,50 & Very Good & 4,50 & Very Good \\
\hline 7 & $\begin{array}{l}\text { Satisfaction related to method } \\
\text { used by lecturer }\end{array}$ & 4,00 & $\begin{array}{l}\text { Good/ } \\
\text { Satisfied }\end{array}$ & 4,00 & $\begin{array}{l}\text { Good/ } \\
\text { Satisfied }\end{array}$ & 4,00 & $\begin{array}{l}\text { Good/ } \\
\text { Satisfied }\end{array}$ \\
\hline 8 & Giving examples & 4,50 & Very Good & 4,50 & Very Good & 4,50 & Very Good \\
\hline 9 & Using learning media & 4,50 & Very Good & 4,50 & Very Good & 5,00 & Very Good \\
\hline 10 & Variation of learning method & 4,00 & Good & 4,50 & Very Good & 4,50 & Very Good \\
\hline \multicolumn{2}{|c|}{ Total Average Score } & 4,25 & Very Good & 4,40 & Very Good & 4,60 & Very Good \\
\hline
\end{tabular}

Table 10 showed the observation result of the learning program in Class Implementation 1, 2, and 3. The total average score for learning program in Class Implementation 1 was 4,25, in Class Implementation 2 was 4,40, and in Class Implementation 3 was 4,60.

2. Description in teaching material management

TABLE 11

MANAGEMENT OF TEACHING MATERIAL IN ClASS IMPLEMENTATION 1, 2, AND 3

\begin{tabular}{|l|l|l|l|l|l|l|l|}
\hline No. & Aspect & $\begin{array}{l}\text { Average } \\
\text { Score of } \\
\text { Class } 1\end{array}$ & Description & $\begin{array}{l}\text { Average } \\
\text { Score of } \\
\text { Class 2 }\end{array}$ & Description & $\begin{array}{l}\text { Average } \\
\text { Score of } \\
\text { Class 3 }\end{array}$ & $\begin{array}{l}\text { Description } \\
4,50\end{array}$ \\
\hline 1 & Convenience & 4,00 & Practical & 4,50 & Very practical & Very practical \\
\hline 2 & $\begin{array}{l}\text { Interconnection between } \\
\text { material and learning } \\
\text { activity }\end{array}$ & 4,00 & Practical & 4,50 & Very practical & 4,50 \\
\hline 3 & $\begin{array}{l}\text { Teaching material as the } \\
\text { main source of learning }\end{array}$ & 4,50 & Very practical & 5,00 & Very practical & 5,00 \\
\hline $\begin{array}{l}\text { Teaching material as the } \\
\text { source of tasks and } \\
\text { exercises }\end{array}$ & 4,50 & Very practical & 5,00 & Very practical & 5,00 \\
\hline 5 & $\begin{array}{l}\text { Teaching material as the } \\
\text { source of values concept }\end{array}$ & $\mathbf{4 , 0 0}$ & Practical & 4,00 & Practical & $\mathbf{5 , 5 0}$ & Very practical \\
\hline
\end{tabular}

Table 11 above showed the observation result of the teaching material management in learning process on Class Implementation 1, 2, and 3. The total average score for teaching material management in Class Implementation 1 was 4 , 20, Class Implementation 2 was 4, 60, andClass Implementation 3 was 4,70. In sum, the three classes were categorized as very practical.

\section{DISCUSSION CONCLUSSION}

Through this research and development, the problems had been resolved. By seeing the results of preliminary field test, main field test, and operational field test, the students had given positive responses to the teaching material. The sample students regarded the developing teaching material as the latest material. It was also interesting, easycomprehended, and free-downloaded with positive effect on learning. It was proven by comparing 100 students' learning result before and after applying material with the percentage of $54 \%$. There were only $22 \%$ students who passed the pre-test and then turned into $76 \%$ students in the post-test. Furthermore, the material was able to invest the values of Makassar local wisdom to the students for its implementation in learning process.

In this research and development, standardized teaching material by the experts had been produced with valid material, presentation systematical, graphic structure, language pattern, and technology/media source. It is clear that the field tests result of the teaching material showed a signicant validity.

The results of this research and development was similar with the research findings by Batari (2014), Rukayah (2013), and Warpala, Subagia, and Suastra (2010) in the production of valid, practical, and effective teaching material through series of systematic process. Teaching material of prose fiction study was supporting by Makassar local wisdom such as honesty (known as malambusuk' in Makassar and lempu'in Buginese), appropriateness (known as assiratang in Makassar and asitinajang in Buginese), persistence (known as tantang ri kontutojeng in Makassar and getteng in Buginese), work hard (known as reso'in Makassar), intellectualism (known as caradek in Makassar and acca' in Buginese), and pride (known as siri' in Makassar) (Rahim, 1985). The other values such as faith, piety, 
courage, and discipline were the students' interpretation in real culture of Makassar local wisdom. As stated by Warpala, Subagia, and Suastra (2010), the research was intended to assert those values and became an effort of introducing and preventing luhung (noble values) from the globalization's attack.

In its relation with moral education, it is true as Abidin (2012) stated that values or moral are quite effective in teaching culture. The development of teaching material based on local wisdom referred to Indonesia's curriculum focusing on the educational development using local wisdom (Susanto, 2014).This breakthrough aimed to raise people's awareness in developing education based on local culture and its potentials. By this research and development, the researcher concluded that the education of cultural values becomes more effective through literature. Because it is a social dimension framed with beautiful language and strong cultural background (Moody, 1971). As we know, the main function of man of letters is to make people realize the meaning of daily life and to reflect things around to be more conceptual and real from the existing (Wellek \& Warren, 1990).

One purpose of this material development was to deepen students' understanding and their ability in critizing and reviewing literature using various approaches or complex methods. There were several advantages of this fiction prose study as a teaching material based on m-learning such as: (a) accessible; (b) applicable; (c) dynamic; and (d) effective in improving students' learning results. These were similiar with the statement from El-Hussein (2010).

Based on previous descriptions of teaching material validity, effectiveness, and practicality, it can be concluded that:

1. The teaching material is appropriate because its validity had been proven through experts and field tests. The average score of the material was 4,32 (high validity), 4,07 for its material presentation(valid), 4,33 for graphic aspect (high validity), 4,19 for language aspect (valid), and 4,19 for the total average score of technology/media (valid). While the average score obtained in the preliminary field test was 3,75 (valid), 4,38 in main field test (high validity), and 4,38 in the operational field test (high validity).

2. The teaching material was effective in improving students' learning result and their understanding of Makassar local wisdom. The test result showed that there was a significant increase where in the pre-test only $22 \%$ students who passed and turned into $76 \%$ in the post-test. Furthermore, the result test showed that there were $91 \%$ students able to find values of local wisdom and connect it with real life condition.

3. The assessment of material implementation proved its high validity by seeing the average scores of learning program evaluation in Class Implementation 1 with the score of 4,25, Class Implementation 2 with the score of 4,40, and Class Implementation 3 with the score of 4,60. Next, the teaching material management which was fully implemented and proven as very practical with the following total averages scores: Class Implementation 1 with the score of 4,20, Class Implementation 2 with the score of 4,60, and Class Implementation 3 with the score of 4,50.

\section{REFERENCES}

[1] Abidin, Yunus. (2012). Pembelajaran Bahasa Berbasis Pendidikan Karakter. Bandung: Refika Aditama.

[2] Abrams, M.H. (1981). A Glossary of Literary Teams. Holt. New York: Rinehart and Winston.

[3] Akker, J. Van den. (1999). Principles and Method of Development Research. London:Dlm.

[4] Ally. (2009). Mobile Learning Transforming the Delivery of Education and Training. Canada: AU Press, Athabasca University.

[5] Aminuddin. (2011). Pengantar Apresiasi Karya Sastra. Bandung: Sinar Baru Algensindo.

[6] Batari, Ulfa Tenri. (2014). Pengembangan Bahan Ajar Bahasa Indonesia Berbasis Cerita Rakyat Siswa Kelas III di Kabupaten Gowa. Disertasi. Makassar. Universitas Negeri Makassar.

[7] Badan Standar Nasional Pendidikan (BSNP). (2006). Instrumen Penilaian Tahap I BukuTeks Pelajaran Pendidikan Dasar Dan Menengah. Jakarta: BSNP.

[8] Dick, Carey \& Carey. (2009). The Systematic Design Of Instruction. Library of Congress Cataloging in Publication Data. Addison-Welswey Educational Publisher Inc.

[9] El-Hussein. (2010). Defining Mobile Learning in the Higher Education Landscape. Journal of Educational Technology \& Society. Vol. 13 (3), 12-21.

[10] Fitrianingrum, Aulia. (2015). Pengembangan Bahan Ajar Digital Berbasis ARCS (Attention-Relevance-ConvidenceSatisfaction) untuk Meningkatkan Keefektifan Pembelajaran Jarimatika dengan Metode Blended Learning di Unit Jarimatika Center Salatiga. Tesis. Perpustakaan Digital UNS.

[11] Jassin, HB. (2008). Harga Diri Sastra Indonesia. Yogyakarta: Indonesia Tera.

[12] Kementrian Pendidikan Nasional. (2010).Pengembangan Pendidikan Budaya dan Karakter Bangsa. Jakarta : Puskur-Balitbang, Kemdiknas.

[13] Moody, H.L.B. (1971). The Teaching of Literature. London: Longman Group Ltd.

[14] Molenda. (2008). Educational Technology A Definition with Commentary. New York: Lawrence Erlbaum Associates.

[15] Opara \& Oguzor. (2011). Inquiry Instructional Method and the School Science Currículum. Champaign: Allyn \& Bacon.

[16] Permana, Cecep Eka. (2010). Kearifan Lokal Masyarakat Baduy dalam Mitigasi Bencana. Jakarta: Wedatama Widya Sastra

[17] Pradopo, Rachmat Djoko. (2011). Kritik Sastra Modern. Yogyakarta: Gama Media.

[18] Prastowo, Andi. (2013). Panduan Kreatif Membuat Bahan Ajar Innovatif. Yogyakarta: DIVA Press.

[19] Rahim, A. Rahman. (1985). Nilai-nilai Utama Kebudayaan Bugis. Makassar: Lembaga Penerbitan Universitas Hasanuddin

[20] Rukayah. (2017). The Development Of Writing Poetry Teaching Material Based on Audiovisual Media of Fifth Grade Elementary School Bone Regency. International Journal of Language Teaching and Research. Vol. 1(1), 113-12.

[21] Rukayah. (2013). Pengembangan Model Pembelajaran Sastra Anak dengan Pendekatan Kooperatif di Sekolah Dasar. Disertasi. Surakarta: Universitas Sebelas Maret Surakarta.

[22] Semi, Atar. (1993). Metode Penelitian Sastra. Bandung : Angkasa. 
[23] Sumarjdo, Jakob, dan Saini K.M. (1994). Apresiasi kesusastraan. Jakarta: Gramedia Pustaka.

[24] Susanto, Ahmad. (2014). Pengembangan Pembelajaran IPS di Sekolah Dasar. Jakarta: Prenadamedia Gorup.

[25] Stanton, Robert. (2012). Teori Fiksi. Yogyakarta: Pustaka Pelajar offset.

[26] Teeuw, A. (1984).Sastra dan Ilmu Sastra: Pengantar Teori Sastra. Jakarta: Balai Pustaka

[27] Traxler, J. (2007). Defining, Discussing and Evaluating Mobile Education. Journal ofInternational Review of Research in Open and Distance Learning. Vol. 8(2), 1-12.

[28] Vavoula dan Sharples. (2009). Towards a Theory of Mobile Learning," Proceedings of M-Learn. Vol. 1(1), 1-9.

[29] Waluyo, Herman J. (1994). Pengkajian Cerita Fiksi. Surakarta: Sebelas Maret University Press.

[30] Wellek, Rene dan Austin Warren. (1993). Teori Kesusastraan (Terjemahan Budiyanto). Jakarta: Gramedia.

[31] Wellek,Rene\& Austin Warren. (1990). Teori Kesusastraan (Terjemahan Melanie Budianta). Jakarta: Gramedia.

Haslinda was born on September $20^{\text {th }}$ 1974. She started her education in SDN Kompleks Mawas, Makassar. Then she joined SMPN 2 Makassar, after graduated she joined SMK 1 Somba Opu, Gowa. She continued her bachelor degree at University of Muhammadiyah Makassar, major in Indonesian Language and Education, then she took her master in the same major at University of Muhammadiyah Makassar.

On 1993-2004 she was a teacher at SMK N 1 Somba Opu, Gowa. Now she is a lecturer at University of Muhammadiyah Makassar. Researches and public services that have been done under the tittle: The Impact of SMS and Slang language to the use of Indonesian Language by the students of University of Muhammadiyah Makassar academic year 2013-2014, the improvement of listening skill by whispered chain method on eight years students at SMP Muhammadiyah Makassar academic year 2013-2014, the improving scientific work learning method based on E-learning on students LPTK Kopertis Wilayah IX Sulawesi academic year 2014-2015.

Journals that have been written: the culture values that contained in the poem of Makassar 2013, the improvement of the ability to appreciate fairy tales through Cooperative Teaching method type Team assisted Individualization on students grade five at SDN Mangasa Gowa 2013, the improvement of the skill writing drama text through poem transformation method on 9 years students at SMP Unismuh Makassar 2013.

Muhammad Rafi Tang, was born in Soppeng in 1960. He graduated his doctoral program in Universitas Negeri Malang, Department of Bahasa Indonesia. He is professor of Language Education and Literature of Faculty of Language Education and Literature in Universitas Negeri Makassar. His scientific paper is La Dado Lele Angkuru-e, Sastra Bugis Klasik (philology study). Lecturer in subject of philology and introduction to Literature, classic literature. His book is Pengantar Kajian Kesusastraan.

Andi Sukri Syamsuri was born in Kabupaten Wajo on Juni $26^{\text {th }} 1971$. He started education in elementary school in SDN 29 Bountouse, Kabupaten Wajo and his high school at SMPnN Tanasitolo Kabupaten Wajo and SPGN Sengkang Kabupaten Wajo. After graduated from high school, he start his education in University at young bachelor degree of Language education and Buginese Art department, faculty of Language, Art and Education. He continued his bachelor degree at Indonesian Language and Education, University Muhammadiyah of Makassar. His master degree was at Indonesian Language post graduate program in Hasanuddin University. His doctoral program was at Indonesian Linguistic, post graduate program in Hasanuddin University of Indonesia.

His job now as a lecture at Islamic State University of Makassar in Art and Humaniora Faculty. Beside that he is outstanding Lecture in several public and private colleges (example supervisor s3).

His complete name and tittles are Dr. Sukri Syamsuri, M.Hum. in addition he has a lot of organization and appreciations like, 1. Exemplary Student of the Republic of Indonesia in 1993, 2. The Former Chairman of Central Association of Student Wajo 1995 1998, 3. The Chairman of the Alumni Association of State SPG Wajo Sengkang Year 2011-2016, 4. The Chairman of the Association of Private Education institutions Education Workforce region IX Sulawesi Indonesia Year 201-2014, 5. The Deputy Secretary of the Association of Indonesia Pembina Branch South Sulawesi. 6. The Chief Executive Teacher Certification Rayon 146 South Sulawesi Mastery of Education and in 2008-2012 2013-2017. 